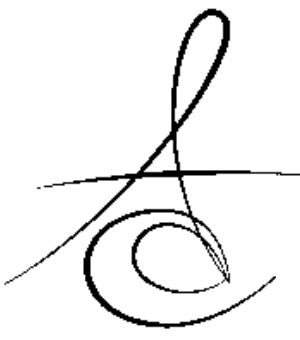

Makale Kodu/Article code: 1859

Makale Gönderilme tarihi: 18.09.2014

Kabul Tarihi: 08.12.2014

\section{APEXOGENESIS OF TRAUMATIZED PERMANENT INCISORS WITH OR WITHOUT TOOTH FRAGMENT}

\section{KIRIK FRAGMANI OLAN VEYA OLMAYAN TRAVMAYA UĞRAMIŞ DAİMİ KESİCİ DİŞLERDE KÖK GELİ̧̧İMİ}

\author{
Yrd. Doç. Dr. Bilge Gülsüm NUR* $\quad$ Yrd. Doç. Dr. Elif YAŞA** \\ Arş. Gör. Dt. Duygu YILDIZELİ**
}

\section{ABSTRACT}

Vital pulp therapy involving partial or cervical pulpotomy can offer a successful outcome for the treatment of traumatic complicated crown fractures. The aim of this clinical study was to evaluate the effect of calcium hydroxide in apexogenesis and maturogenesis of traumatized immature permanent incisors with pulp exposure.

According to clinical and radiological examinations, complicated crown fractures and open apices of two permanent maxiller incisors in two patients were identified ( 9 and 10 years old, respectively). Partial or cervical pulpotomy procedures were performed according to post traumatic time and teeth were treated with calcium hydroxide. In this study, periodic clinical and radiological follow-ups were performed in $1,3,6,12$ and 24 months. At recall examinations, teeth were asymptomatic, clinical and radiological investigations revealed excellent healing patterns with continued apexogenesis and maturation.

Vital pulp therapy is a treatment for immature traumatized permanent teeth in order to preserve vitality and physiological root development by using calcium hydroxide medication. Adhesive reattachment of tooth fragment is the most conservative treatment when the tooth fragment is available and also more advantageous than conventional composite restorations.

Key words: Apexogenesis, Vital pulp therapy, Complicated Crown Fractures,

\section{ÖZET}

Kısmi veya servikal pulpotomi tedavisini içeren vital pulpa tedavisi travmatik komplike kron kırıklarının tedavisinde başarılı sonuç sunabilmektedir. Bu klinik çalışmanın amacı kök gelişimini tamamlamamış ve pulpası açığa çıkmış genç daimi dişlerde kalsiyum hidroksidin kök ucu kapanması ve olgunlaşmasına olan etkisini değerlendirmektir.

Klinik ve radyografik değerlendirmeler sonucunda, yaşları 9 ile 10 arasında değişen iki hastanın kök gelişimi tamamlanmayan üst çene ön kesici daimi dişlerinde komplike kron kırı̆ı tespit edildi. Travmadan sonra başvuru zamanı göz önüne alınarak dişlere parsiyel veya servikal pulpatomi tedavisi uygulandı ve dişler kalsiyum hidroksit ile tedavi edildi. Çalışmada periyodik klinik ve radyolojik takipler $1,3,6,12$ ve 24 aylarda yapıldı. Takip esnasında dişlerde her hangi bir semptom görülmedi. Ayrıca takip süresince hem klinik hem de radyolojik olarak dişlerde kök gelişiminin ve olgunlaşmasının devam ettiği görüldü.

Vital pulpa tedavisi kalsiyum hidroksit kullanarak kök gelişimini tamamlamamış daimi dişlerde, dişlerin vitalitesi ve fizyolojik kök gelişimini korumak amacıyla uygulanan bir tedavi yöntemidir. Travmatik yaralanmalarda, eğer mevcut ise kırık parçanın kalan diş üzerine yapıştırıması geleneksel kompozit ile dolgu yapılmasına oranla daha avantajlıdır.

Anahtar kelimeler: Kök gelişimi, Komplike kron kırı̆ı̆ı, Vital pulpa tedavileri

\footnotetext{
*Şifa Üniversitesi, Diş Hekimliği Fakültesi, Pedodonti Anabilim Dalı

"Şifa Üniversitesi, Diş Hekimliği Fakültesi, Tedavi Anabilim Dalı
} 


\section{INTRODUCTION}

The most frequently encountered dental trauma type involves the maxillary permanent incisors due to their position in the $\operatorname{arch}^{1}$. Various etiological factors can cause to complicated crown fracture injuries such as falls, contact sports, automobile accidents, foreign body striking the teeth and others ${ }^{2-}$ ${ }^{4}$. Complicated crown fractures caused by dental trauma that mainly affect children and adolescents in permanent dentition(18-20\% $)^{5-7}$. There are many ways to treat the complicated crown fractures such as direct pulp capping, pulpotomy (partial or cervical) or pulpectomy ${ }^{8}$. The treatment prognosis depending on different factors including the interval between accident and dental examination, degree of root development and size of pulp exposure or presence/absence of fractured tooth fragment ${ }^{9,10}$.

Vital pulp therapy (VPT), In other words direct pulp capping or partial-cervical pulpotomy or pulpectomy should be performed only in teeth with reversible pulpitis with no periapical pathologies ${ }^{11,12}$. At the same time this treatment choiced for traumatized or carious teeth with vital pulp and open apices on pulp exposure ${ }^{13,14}$. Firstly, success of VPT depends on grade of pulp injury and length of time after exposure of the pulp to the oral environment. Secondly, it depends on which technique is performed and type of the agent is used $^{14-16}$. Additionally, usage of a biocompatible agent to support healing and continuing vitality of the remaining pulp tissue is highly important in the treatment of the complicated crown fractures ${ }^{14,17}$.

To date, Calcium hydroxide $(\mathrm{CH})$ and MTA commonly used medicaments in VPT. These materials have good physical characteristics, biocompatibility and several cases presenting successful clinical outcomes $^{9,18-20}$. Based on in vivo studies, MTA is accepted as a suitable pulp capping material ${ }^{20}$. However, a long setting time, high cost, potential for discoloration and unpredictable antibacterial properties are some of the disadvantages of MTA $^{21}$. Recently, two new biomaterials were developed that called calcium enriched mixture (CEM) cement and tricalcium silicate cement (Biodentine). In vitro studies show that these materials have good mechanical properties, low cytotoxicity and strong antimicrobial effect, but no long-term clinical studies were found in the literature ${ }^{22,23}$.
Studies have suggested that VPT acquire ideal clinical outcomes independent of the material ${ }^{20,22-24}$. Calcium hydroxide is the gold standard for pulp capping material in the literature and it has been choice of material in VPT for many decades ${ }^{25}$. Calcium hydroxide accepted to many biological properties including antibacterial, antifungal activity and promoting stem cell survival and proliferation ${ }^{26}$. Furthermore, it is still the most accessible material and dentists can perform easily in clinics ${ }^{14}$.

This article report two cases of traumatized permanent maxillary lateral incisors. We assessed the size of pulpal exposure, the existence of tooth fragment together with the patient, interval between accident and treatment and stage of root development of teeth by using $\mathrm{CH}$.

\section{CASE REPORT 1}

A 10-year-old male presented to our clinic with a complicated crown fracture of his right maxillary lateral incisor and enamel fracture of left maxillary central incisor (Fig. 1). His general health history revealed no systemic diseases. The trauma, which was caused by a cycling accident occurred about ten days earlier and the tooth fragment was not available. Intraoral examination showed that gingival inflammation of maxillary incisor region and large pulpal exposure on right lateral incisor, but no laceration, mobility, root fracture, soft tissue damage or alveolar bone fracture. The patient experienced pain on stimulus. Radiological examination revealed that fractured tooth had incomplete root growth.

Detailed information was given to parents about possible discomfort and risks. Based on clinical and radiographical examinations, reversible pulpitis was diagnosed in fractured tooth. Treatment was carried out under local anesthesia and tooth was isolated with a rubber dam. The pulp was removed using a diamond bur on a high speed handpiece with water cooling. Bleeding was controlled with a sterile saline solution and pulpal tissue was dried with a sterile cotton pellet. Considering the immaturity of tooth and interval between accident and examination cervical pulpotomy procedures were performed and tooth was treated with $\mathrm{CH}$. 
Calcium hydroxide (Kalsin,Sultan,USA) powder was freshly mixed with distilled water according to manufacturer's instructions and put without pressure over exposed clot-free pulpal wound. The exposed dentin and $\mathrm{CH}$ were both sealed with glass ionomer cement (GIC, Ketac Molar, 3M ESPE, St. Paul, USA) and fractured surfaces were restored with composite resin (Filtek Ultimate, 3M ESPE, St. Paul, USA). Additionally, enamel fracture of left maxillary central incisor was restored with the same composite resin. Approximately four months later composite restoration was removed and tooth was acid etched for 20 s with a 37\% phosphoric acid gel (Scotchbond Etchant, 3M ESPE, St. Paul, USA), rinsed for 20 seconds and air dried. Then, a conventional two-bottle adhesive system (Scotchbond Multi Purpose, 3M ESPE, St. Paul, USA) was applied on the coronal portion of the root and tooth surface, later light-cured. After bonding procedure fractured tooth was finished functionally and aesthetically with composite resin using $A 2$ Dentin/Enamel shades (Filtek Ultimate, 3M ESPE, St. Paul, USA). Later the restored surface was finished and polished (Sof-Lex disks, 3M ESPE, St Paul, USA). Occlusion was checked and post operative instructions to the patient were given to abstain from loading on the anterior teeth (Fig. 2). The patient was recalled in 1, 3, 6 and 12 months (Fig. 3).

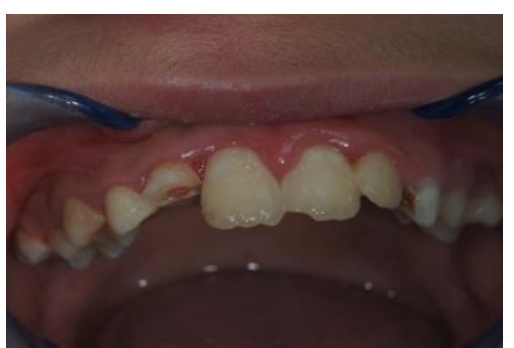

Figure 1. Preoperative- intraoral photograph

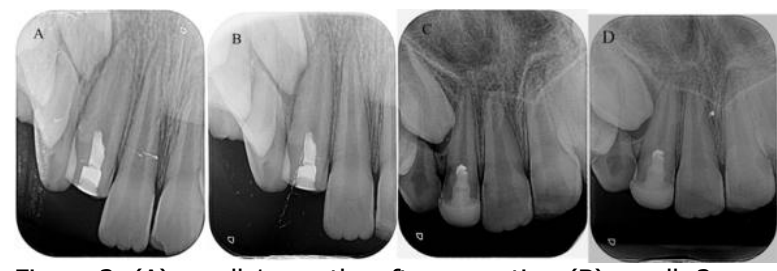

Figure 3. (A) recall 1 months after operation;(B) recall 3 months after operation; (C) recall 6 months after operation; (D) recall 12 months after operation

\section{CASE REPORT 2}

A nine year-old female patient referred to our clinic with a complicated horizontal crown fracture in the right upper lateral incisor during fall (Fig.4). The patient applied to the department within two hours after injury. The fractured tooth fragment was recovered by the patient at the site of the injury and kept in tap water. The tooth fragment was immediately maintained in saline to prevent discoloration due to dehydration during the whole period prior to restoration. Initial examination revealed a complicated horizontal fracture that extended subgingivally on the palatal area. Following detailed intraoral and radiographical examination, $1 \mathrm{~mm}$ pulpal exposure was observed and incomplete root growth was determined on upper right lateral. Besides there was no observed laceration, mobility, root fracture, soft tissue damage or alveolar bone fracture. Her general health history revealed no systemic diseases. Considering immaturity of the tooth and interval between accident and examination, partial pulpotomy procedures were performed. Treatment was carried out under local anesthesia and the tooth was isolated with a rubber dam. The superficial layer of the exposed pulp was excised to a depth of $2 \mathrm{~mm}$ using a diamond bur with water cooling. Bleeding was controlled with sterile saline solution, the pulpal wound was dried with sterile cotton pellet and covered with $\mathrm{CH}$ (Kalsin, Sultan, USA). Powder was freshly mixed with distilled water according to manufacturer's instructions and put over the pulp. The exposed dentin and $\mathrm{CH}$ were both sealed with GIC (Ketac Molar, 3M ESE, St Paul, USA). Following a detailed examination, daptation of the fragment was checked. Small grooves were prepared in the inner portion of the fractured coronal fragment. After isolation of the fractured tooth, acid etching of both fragment and remaining tooth surface was applied for 20 seconds using $37 \%$ phosphoric acid (Scotchbond Etchant, 3M
Figure 2. (A) Post operative - frontal view; (B) Lateral view; (C) Occlusal view.

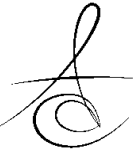


ESPE, St Paul, USA) and then rinsed completely with water and air dried. Following, conventional two-bottle adhesive system (Scotchbond Multi Purpose, 3M ESPE, St Paul, USA) was applied on both tooth surface and fractured fragment. Later, flowable composite resin (Filtek Ultimate, 3M ESPE, St Paul, USA) was used to fill the access cavity in the tooth and prepared grooves into the coronal fragment. The fragment was carefully placed on the remaining tooth and light cured for 30 seconds on both sides of the tooth. After curing, excess composite was removed with a diamond finishing bur and final polishing was performed (SofLex disks, 3M ESPE, St Paul, USA) (Fig. 5).

After treatment, occlusion was checked and post operative instructions were given to the patient to avoid loading on the anterior teeth. Pulp sensitivity was tested after 24 hours. Follow up examinations were carried out at $1,3,6,12$ and 24 month intervals (Fig. 6).

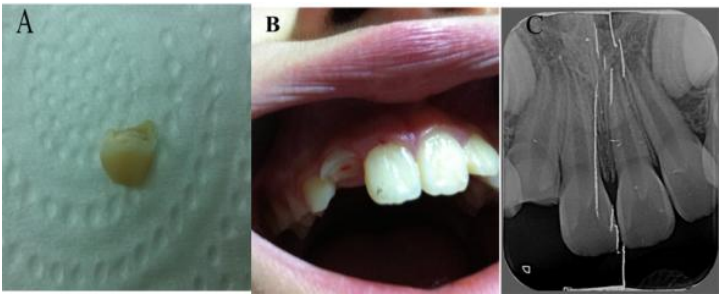

Figure 4. (A) Fragments; (B) Preoperative-frontal view. (C) Radiographic image of the fractured tooth.

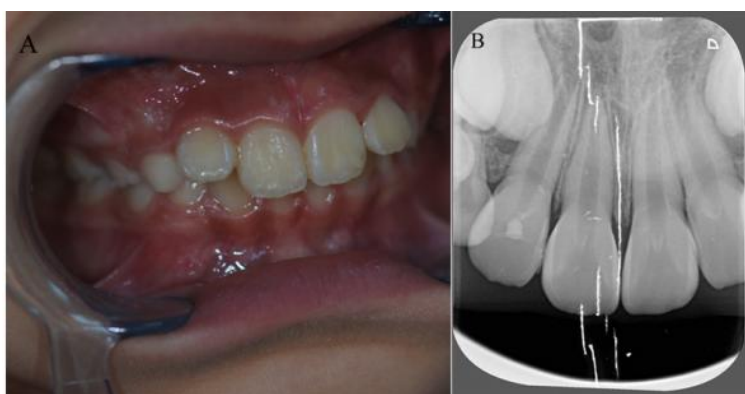

Figure 5. (A)Reattachment of fracture fragment and final restoration. (B) Postoperative radiograph -pulp capping with Calcium hydroxide-

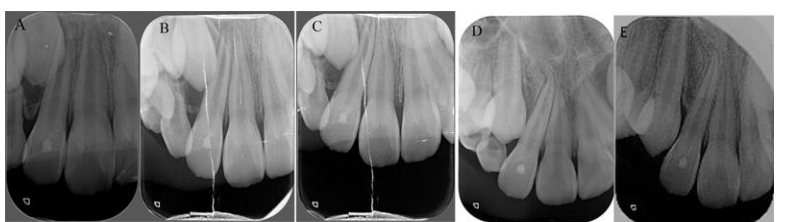

Figure 6. (A) recall 1 months after operation;(B) 3 months after operation; (C) 6 months after operation; (D) 12 months after operation; (E) 24 months after operation

\section{DISCUSSION}

Vital pulp therapy (VPT) has remarkable importance in young permanent teeth to protect the pulp vitality ${ }^{18}$. When this treatment is carried out successfully, healthy pulp provides apical development and promotes deposition and maturation of lateral root dentine ${ }^{27}$. Apexogenesis supports the maturation of very thin and weak root walls with continued physiologic development and formation of root's apex. This procedure also called VPT involves pulp capping or partial or cervical pulpotomy and preferred for teeth with complicated crown fracture with vital pulp and open apices ${ }^{8,17}$.

Complicated crown fractures usually lead to the contamination of pulp by saliva and oral bacteria. During the first 24 hours inflammation is limited in superficial layer of the pulp, after this stage, inflammation spreads apically ${ }^{28}$. Previous studies reported that exposed dental pulp has healing potential when bacterial leakage has prevented ${ }^{29-31}$. According to interval between accident and examination, treatment performed by direct pulp capping or pulpotomy (partial or cervical) or pulpectomy and remaining pulp covering with suitable capping biomaterials ${ }^{17,25}$.

Amini et al. ${ }^{32}$ reported a case of an eight years old girl who was treated for complicated crown fracture of right maxillary central incisor. The treatment protocol, pulpotomy was performed in order to achieve apexogenesis. The tooth was restored with a composite resin and patient was reviewed over 10 years. Following vital pulp therapy, the tooth showed continued root development and complete apex formation however, after 10 years the tooth developed pulp necrosis and periapical radiolucency.

Cvek. ${ }^{25}$ reported 83 traumatized immature permanent incisors with complicated crown fractures. The treatment of these teeth applied partial pulpotomy and calcium hydroxide paste used as a capping agent. The study showed that successful results in the treatment of complicated crown fractures was $96 \%$. In another study, Fuks. ${ }^{33}$ reported 63 traumatized permanent incisors (10 were immature and 53 were mature) with complicated crown fractures. The treatment of these teeth applied partial pulpotomy and success rate of treatment was $94 \%$. In this case reports, considering the period of pulpal

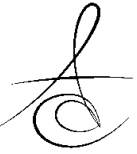


exposure, we performed cervical pulpotomy or partial pulpotomy. When compared to cervical pulpotomy partial pulpotomy provides a better healing potential, preservation of cell-rich coronal pulp tissue and a subsequent root canal treatment is not necessary.

Several studies reported that partial pulpotomy of carious exposed immature permanent teeth demonstrated favorable outcomes capped with $\mathrm{CH}^{13,14,24,34}$. The capping material must be biocompatible, bactericidal, able to provide a biologic and bacterial-tight seal and induce hard tissue formation of immature permanent teeth ${ }^{17}$. Although many new agents were introduced in dentistry, $\mathrm{CH}$ is still a well-accepted material to stimulate dentin formation of immature permanent teeth and dentists can perform easily in clinics for many decades ${ }^{14,18,24,35}$.

The physical characteristics and biocompatible properties of $\mathrm{CH}$ enhanced the success rate of treatment ${ }^{24,25}$. This success may be related with the high alkalinity of $\mathrm{CH}$. Its calcium release and sustained $\mathrm{pH}$ of 12,4 most likely prevents any further microbial growth of surviving microorganisms and stimulates dentin formation after trauma of immature permanent teeth $^{14}$.

For this reason, in this study we treated traumatized teeth with the VPT protocol by using coronally packed $\mathrm{CH}$ paste. Later, composite resin or reattachment of the tooth fragment were employed.

When the fractured fragment is unavailable, traumatized anterior teeth need quick functional and aesthetic repair ${ }^{36}$. The psychological trauma caused to the adolescent patient due to loss of aesthetics can be treated by this procedure successfully.

Composite materials are commonly used for aesthetic rehabilitation of crown fractures ${ }^{37}$. Recently, there has been observed remarkable advancement of adhesive technology and resin composites which include flowable composites, nanohybrid and microfilled light-cured, dual-cured composites and chemically cured composites in restorative dentistry ${ }^{1}$. In these cases we used nanohybrid composites. These composites provide long-lasting polished surfaces, excellent handling and a wear rate similar to enamel.

According to presence/absence of fractured tooth fragment, two treatment options are suitable to treat the complicated crown fractures. Whenever the fractured fragment is available intact, reattachment of tooth fragments should be the first treatment of choice. For this reason, we reattachment of tooth fragments in case report 2 . Clinical studies and longterm follow-up have confirmed that reattachment used to advanced adhesive technology may achieve functional and aesthetics success than conventional method $^{10,38,39}$.

Reattachment of fragment may offer various advantages compared with conventional method such as being economical, safe and a less time consuming procedure, providing natural aesthetics with a very conservative approach, a positive emotional and social feedback from the patient ${ }^{40}$. This treatment can be applied only when the intact tooth fragment is available $^{41}$. de Lima Mde et al. ${ }^{42}$ performed reattachment of fractured fragment of an anterior tooth with nine-year follow-up. Similarly, Martos et al. ${ }^{43}$ reported reattachment of maxillary right lateral incisor with 5 year follow-up. They confirmed that reattachment of the fractured fragments simple, longlasting esthetics and improved function with a very conservative approach. ${ }^{42,43}$ In this case reports we concluded that there is not intra-pulpal or periapical pathosis with continued root development could be detected radiographically in immature teeth.

\section{CONCLUSION}

Traumatic injuries influence an aesthetics, physical and psychological development of adolescent patients. In this study, clinical and radiological findings confirm that partial and/or cervical pulpotomy treatment with $\mathrm{CH}$ is still a reliable and effective approach for preserving vitality and physiological root development. If the fractured fragment is available, reattachment of the intact fractured segment can be considered as a conservative, safe, fast method for aesthetic rehabilitation.

\section{Acknowledgments}

The authors deny any conflicts of interest related to this study.

\section{REFERENCES}

1. Macedo GV, Diaz PI, De OFCA, Ritter AV. Reattachment of anterior teeth fragments: a conservative approach. J Esthet Restor Dent 2008;20: 5-18;9-20.

2. Andreasen JO. Etiology and pathogenesis of traumatic dental injuries. A clinical study of 1,298

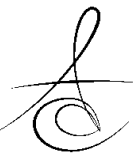


cases. Scand J Dent Res 1970;78: 329-42.

3. Evcil S AH, Harorlı A. Sporda dental travmalar ve tedavileri. Atatürk Üniv BESYO, Beden Eğit ve Spor Bil Derg 1999;1:58-60.

4. Özel E, Altundal H. Dentoalveolar ve perioral yumuşak doku yaralanmaları. Atatürk Üniv Diş Hek Fak Derg 2006:7-13.

5. Tuğut $F$, Ünal $M$, Kapdan $A$, Demir $H$, Doğan $\mathrm{OH}$. Komplike kuron kırığı olgusunda cam fiber post destekli kompozit restorasyonu: Olgu raporu ve 18 aylık takip. Atatürk Üniv Diş Hek Fak Derg 2009;19: 207-12.

6. Hamilton FA, Hill FJ, Holloway PJ. An investigation of dento-alveolar trauma and its treatment in an adolescent population. Part 2: Dentists' knowledge of management methods and their perceptions of barriers to providing care. Br Dent J 1997;182:12933.

7. Sarı $M E$, Külünk $T$, Koyutürk $A E$. Ön diş kuron kırıklarının fiber post ve kompozit rezin ile restorasyonu: 3 olgu sunumu. Atatürk Üniv Diş Hek Fak Derg 2007;2:51-4.

8. Nosrat A, Asgary S. Apexogenesis treatment with a new endodontic cement: a case report. J Endod 2010;36:912-4.

9. Olsburgh $\mathrm{S}$, Jacoby $\mathrm{T}$, Krejci I. Crown fractures in the permanent dentition: pulpal and restorative considerations. Dent Traumatol 2002;18:103-15.

10. Andreasen FM, Noren JG, Andreasen JO, Engelhardtsen $S$, Lindh-Stromberg $U$. Long-term survival of fragment bonding in the treatment of fractured crowns: a multicenter clinical study. Quintessence Int 1995;26: 669-81.

11. Al-Hiyasat AS, Barrieshi-Nusair KM, Al-Omari MA. The radiographic outcomes of direct pulp-capping procedures performed by dental students: a retrospective study. J Am Dent Assoc 2006;137:1699-705.

12. Souza RA, Gomes SC, Dantas Jda C, Silva-Sousa $\mathrm{YT}$, Pecora JD. Importance of the diagnosis in the pulpotomy of immature permanent teeth. Braz Dent ] 2007; 18:244-7.

13. Mejare I, Cvek M. Partial pulpotomy in young permanent teeth with deep carious lesions. Endod Dent Traumatol 1993;9: 238-42.

14. Bacaksız A, Alacam A. Induction of maturogenesis by partial pulpotomy: 1 year follow-up. Case Rep Dent 2013;2013: 975834.
15. Heide S, Mjor IA. Pulp reactions to experimental exposures in young permanent monkey teeth. Int Endod J 1983;16:11-9.

16. Waterhouse PJ, Nunn JH, Whitworth JM, Soames JV. Primary molar pulp therapy--histological evaluation of failure. Int $\mathrm{J}$ Paediatr Dent 2000;10:313-21.

17. Witherspoon DE. Vital pulp therapy with new materials: new directions and treatment perspectives--permanent teeth. J Endod 2008;34:25-8.

18. Weisleder R, Benitez CR. Maturogenesis: is it a new concept? J Endod 2003;29:776-8.

19. Patel R, Cohenca N. Maturogenesis of a cariously exposed immature permanent tooth using MTA for direct pulp capping: a case report. Dent Traumatol 2006;22:328-33.

20. Abarajithan M, Velmurugan N, Kandaswamy D. Management of recently traumatized maxillary central incisors by partial pulpotomy using MTA: Case reports with two-year follow-up. J Conserv Dent 2010;13:110-3.

21. Asgary S, Eghbal MJ, Parirokh M, Torabzadeh $\mathrm{H}$. Sealing ability of three commercial mineral trioxide aggregates and an experimental root-end filling material. Iran Endod J 2006;1:101-5.

22. Villat C, Grosgogeat B, Seux D, Farge P. Conservative approach of a symptomatic carious immature permanent tooth using a tricalcium silicate cement (Biodentine): a case report. Restor Dent Endod 2013;38: 258-62.

23. Nosrat A, Asgary S, Eghbal MJ, Ghoddusi J, BayatMovahed S. Calcium-enriched mixture cement as artificial apical barrier: A case series. J Conserv Dent 2011; 14:427-31.

24. Cehreli ZC, Isbitiren B, Sara S, Erbas G. Regenerative endodontic treatment (revascularization) of immature necrotic molars medicated with calcium hydroxide: a case series. ] Endod 2011;37:1327-30.

25. Cvek M. A clinical report on partial pulpotomy and capping with calcium hydroxide in permanent incisors with complicated crown fracture. J Endod 1978; 4:232-7.

26. Althumairy RI, Teixeira FB, Diogenes A. Effect of dentin conditioning with intracanal medicaments on survival of stem cells of apical papilla. J Endod 2014;40:521-5. 
27. Belobrov I, Weis MV, Parashos P. Conservative treatment of a cervical horizontal root fracture and a complicated crown fracture: a case report. Aust Dent J 2008;53:260-4.

28. Cvek M, Cleaton-Jones PE, Austin JC, Andreasen JO. Pulp reactions to exposure after experimental crown fractures or grinding in adult monkeys. J Endod 1982;8: 391-7.

29. Cvek M, Granath L, Cleaton-Jones P, Austin J. Hard tissue barrier formation in pulpotomized monkey teeth capped with cyanoacrylate or calcium hydroxide for 10 and 60 minutes. J Dent Res 1987;66:1166-74.

30. Cox CF, Bergenholtz G, Fitzgerald M, Heys DR, Heys RJ, Avery JK, et al. Capping of the dental pulp mechanically exposed to the oral microflora a 5 week observation of wound healing in the monkey. J Oral Pathol 1982;11:327-39.

31. Cox CF, Bergenholtz G, Heys DR, Syed SA, Fitzgerald M, Heys RJ. Pulp capping of dental pulp mechanically exposed to oral microflora: a 1-2 year observation of wound healing in the monkey. J Oral Pathol 1985; 14:156-68.

32. Amini $P$, Parirokh $M$. The importance of long time follow-up after vital pulp therapy: a case report. Iran Endod J 2008;3:90-2.

33. Fuks $A B$, Klein $H$, Eidelman $E$. Partial pulpotomy as a treatment alternative for exposed pulps in crown-fractured permanent incisors. Endod Dent Traumatol 1987;3:100-2.

34. Mass E, Zilberman U. Clinical and radiographic evaluation of partial pulpotomy in carious exposure of permanent molars. Pediatr Dent 1993;15:257-9.

35. Bose R, Nummikoski P, Hargreaves K. A retrospective evaluation of radiographic outcomes in immature teeth with necrotic root canal systems treated with regenerative endodontic procedures. J Endod 2009; 35:1343-9.

36. Koyuncuoğlu G, Görken FG, İkikarakayalı G, Zorlu S, Erdem AP, Sepet E, Aren G. Management of open apices in thirteen traumatized permanent incisors using mineral trioxide aggregate:Case series. Pediatr Dent Journal 2013;23:51-6

37. Altun C, Tozum TF, Guven G. Multidisciplinary approach to the rehabilitation of a crown fracture with glass-fibre-reinforced composite: a case report. J Can Dent Assoc 2008;74:363-6.
38. Oz IA, Haytac MC, Toroglu MS. Multidisciplinary approach to the rehabilitation of a crown-root fracture with original fragment for immediate esthetics: a case report with 4-year follow-up. Dent Traumatol 2006;22:48-52.

39. Hürmüzlü F. Travma sonucu kırılan üst santral dişlerde orijinal diş parçasının yeni adesiv sistem ile yapıştırılması. Cumhuriyet Üniv Diş Hek Fak Derg 2002;5:89-91.

40. Hegde RJ. Tooth fragment reattachment--an esthetic alternative: report of a case. J Indian Soc Pedod Prev Dent 2003;21:117-9.

41. Simonsen RJ. Traumatic fracture restoration: an alternative use of the acid etch technique. Quintessence Int Dent Dig 1979;10:15-22.

42. de Lima Mde D, Martins JF, de Moura MS, Leao VL, Moura Lde F. Reattachment of fractured fragment of an anterior tooth: case report and nine-year follow-up. Gen Dent 2011;59:192-5.

43. Martos J KC, Silveira LFM, Neto JBC. Crown fragment reattachment in anterior-fracture tooth:a five-year follow up. Eur J Gen Dent 2012;1:112-5.

\section{Yazışma Adresi}

Yrd. Doç. Dr. Bilge Gülsüm NUR

Şifa Üniversitesi, Diş Hekimliği Fakültesi, Pedodonti Anabilim Dalı

Mansuroğlu Mah. 293/1 Sk. No:2, 35100,

Bayraklı, İzmir/Türkiye

Tel: +90 232 3080000, Fax: +90 2324864147

E-mail: dtbilgenur@hotmail.com 